\title{
Chemical composition and carbohydrate content of several varieties of faba bean and pea seeds*
}

\author{
Jolanta Gdala and Lucyna Buraczewska \\ The Kielanowski Institute of Animal Physiology and Nutrition, \\ Polish Academy of Sciences \\ 05-110 Jablonna, Poland
}

(Received 18 November 1996; accepted 6 February 1997)

\begin{abstract}
The chemical composition of mature whole seeds of four cultivars of faba bean (Vicia faba L.), seven cultivars of white-flowered pea (Pisum sativum hortense L.) and two cultivars of coloured-flowered pea (Pisum sativum arvense L.) was determined with special emphasis on carbohydrates. The average content (per kg DM) of total and enzyme-susceptible starch in faba beans, white- and coloured-flowercd peas was 430 and $367 \mathrm{~g}, 461$ and $419 \mathrm{~g}$, and 459 and $390 \mathrm{~g}$, respectively. Faba beans contained less $\alpha$-galactosides ( 28 vs. $58 \mathrm{~g}$ ) than peas. Verbascose was the main constituent ( $16 \mathrm{~g}$ on average) of faba bean $\alpha$-galactosides, while verbascose $(26 \mathrm{~g})$ and stachyose $(24 \mathrm{~g})$ were the major $\alpha$-galactosides in pea seeds. Faba beans contained, on average, $177 \mathrm{~g}$ non-starch polysaccharides (NSP), while the level of these polysaccharides in pea secds amounted to $183 \mathrm{~g}$. In faba beans and in pea seeds, NSP were composed mainly of glucose, arabinose and uronic acids. In general, there were no significant differences among cultivars within each species in terms of NSP content and their chemical composition.
\end{abstract}

KEY WORDS: faba bean, pea, carbohydrates, composition

\section{INTRODUCTION}

Although the nutritional value of faba beans and peas is lower than that of a good quality soyabean meal, these legumes are an important source of supplemental protein in animal diets. The content and amino acid composition

* The research was financed by grant No 5 \$30503305 from the Commitlee for Scientific Research 
of protein in faba beans and peas have been widely reported in literature (Marquardt et al., 1975; Thacker and Bowland, 1985). The toxic compounds present in faba beans and peas that adversely affect the availability and utilization of nutrients are also well characterized (Griffiths, 1983; Savage, 1989). But only little information is available on the seed carbohydrate composition (Cerning-Breoard and Filiatre, 1976; Dandanell and Åman, 1993) and their nutritional value (Longstalf and $\mathrm{McNab}, 1987$ ). Therefore, the present study was undertaken to characterize the chemical composition of faba beans and peas with special reference to carbohydrates. The nutrient contents were evaluated in cultivars of Vicia faba, Pisum sativum hortense and Pisum sativum arvense for three consecutive years of growth.

\section{MATERIAL AND METHODS}

Seeds

Seeds of four cultivars (Alen, Kamir, Martin, Tibo) of faba bean (Vicia faba L.), seven cultivars (Diament, Kama, Kwestor, Piast, Sol, Jaran, Ametyst) of white-flowered pea (Pisum sativum hortense L.) and of two cultivars (Grapis, Fidelia) of coloured-flowered pea (Pisum sativum arvense L.) were used in the present study. With the exception of Jaran pea (a leafless cultivar) and Ametyst (green seeds) other white-flowered peas had typical leaves and smooth, white sceds. Five-kilogram samples of seeds were taken from five Plant Breeding Stations located in different regions of Poland. Every cultivar originated from the same station for three consecutive years of collection.

\section{Analytical procedure}

Dry matter (DM), nitrogen (N), fat, ash, crude fibre (CF), and total starch were analyzed using standard methods (AOAC, 1990). Enzyme susceptible starch was determined according to the procedure of Megazyme (TSA 9/92). The samples were heated in the presence of thermostable $\alpha$-amylase under controlled conditions and the reaction was terminated with $2 \mathrm{ml}$ of $0.2 \%$ sulphuric acid. The content of neutral detergent fibre (NDF), acid detergent fibre (ADF), acid detergent lignin (ADL), hemicellulose, cellulose, sucrose, $x$-galactosides and total NSP and their constituent sugars were determined according to methods described in our earlier publication (Gdala and Buraczewska, 1996). Condensed tannins were analyzed by the vanillin method according to Kuhla and Ebmeier (1981). Activity of trypsin inhibitors was determined by the method of Kakade et al. (1974), as modified by van Oort et al. (1989) for faba been analysis. The results 
are expressed in trypsin inhibitor units per mg dry matter (TUI/mg DM) which is defined as the quantity of enzyme which induces an increase of 0.01 in absorbance.

\section{Statistical analysis}

The average over three years and standard deviation were calculated for each analyzed component of faba bean and pea seeds. The data were statistically analyzed using multifactorial analysis of variance taking into account as the factors the effect of cultivar within each species and year of growth (Statgraphics Plus v. 7.0, 1993).

\section{RESULTS AND DISCUSSION}

\section{Vicia faba}

The weight of one thousand beans ranged from 464 to $497 \mathrm{~g}$ and was lower than that reported by Griffiths (1981) (425-814 g). Neither cultivar nor year of growth influenced the weight of faba beans (Table 1). In contrast, both factors significantly affected the content of crude protein, which ranged from 277 to 306 g per kg DM. A higher level of crude protein (310-330 g/ kg DM) in eight cultivars of faba bean was reported by Marquardt et al. (1975). A comparison of the basic composition of four cultivars of faba bean indicated no significant differences among them in the content of ether extract (13-15 g), ash (33-38 g), total starch (405-445 g), enzyme susceptible starch (347-378 g), NSP (173-181 g), NDF (139-155 g), ADF (110-116 g) and CF (74-83 g). It was observed, however, that the year of growth significantly affected the content of ether extract and ADL in faba beans. Hemicellulose, in comparison with cellulose (about $100 \mathrm{~g}$ ), constituted only a small proportion (24-45 g) of faba bean dry matter. Cerning-Bernard and Filiatre (1976) found about $40 \mathrm{~g}$ of hemicellulose in faba bean cv. Bianka.

Faba beans contain several anti-nutritional factors, mainly tannins and trypsin inhibitors, which may impair animal performance if their dietary level is too high. Tannins (catechin equivalent), located mainly in the seed coats, were found to be present in a range from 7.8 to $9.8 \mathrm{mg} / \mathrm{g} \mathrm{DM}$. The level of these undesirable factors depended $(P=0.032)$ on the year of growth. The levels of condensed tannins in faba beans reported by Telek and Miklas (1993) ranged from 4.1 to $5.6 \mathrm{mg} / \mathrm{g} \mathrm{DM}$. In contrast, Saini (1993) found only $1.01-1.85 \mathrm{mg} / \mathrm{g}$ of these compounds in nine cultivars of faba beans. In this case, however, the assay procedure was different than that used in the current study. There is evidence that 
TABLE 1

Chemical composition of faba beans, $\mathrm{g} / \mathrm{kg} \mathrm{DM}$

\begin{tabular}{|c|c|c|c|c|c|c|c|}
\hline & \multicolumn{4}{|c|}{ Faba bean } & \multirow{3}{*}{ SEM } & \multicolumn{2}{|c|}{ Effect of } \\
\hline & Alen & Kamir & Martin & Tibo & & year & cultivar \\
\hline n & 3 & 3 & 3 & 3 & & \multicolumn{2}{|c|}{$\mathrm{P}<$} \\
\hline Weight of 1000 seeds, $g$ & 489 & 497 & 464 & 491 & 11.24 & & \\
\hline Dry matter & 874 & 891 & 894 & 884 & 4.40 & & \\
\hline Crude protein & 297 & 306 & 277 & 282 & 5.80 & 0.001 & 0.012 \\
\hline Ether extract & 14 & 13 & 15 & 13 & 0.21 & 0.001 & \\
\hline Ash & 36 & 34 & 33 & 38 & 0.51 & & \\
\hline Total starch & 436 & 405 & 445 & 434 & 5.50 & & \\
\hline $\begin{array}{l}\text { Enzyme susceptible } \\
\text { starch }\end{array}$ & 378 & 347 & 373 & 377 & 4.70 & & \\
\hline Fibre fraction: & & & & & & & \\
\hline NSP & 177 & 173 & 175 & 181 & 0.96 & & \\
\hline NDF & 139 & 140 & 155 & 142 & 3.46 & & \\
\hline ADF & 116 & 112 & 110 & 111 & 2.02 & & \\
\hline $\mathrm{CF}$ & 83 & 80 & 79 & 74 & 1.20 & & \\
\hline $\mathrm{ADL}$ & 14 & 10 & 10 & 8 & 0.62 & 0.002 & \\
\hline hemicellulose & 24 & 27 & 45 & 31 & 3.75 & & \\
\hline cellulose & 101 & 102 & 100 & 102 & 2.19 & & \\
\hline $\begin{array}{l}\text { Antinutritional factors: } \\
\text { tannins, } \mathrm{mg} / \mathrm{g} \\
\text { trypsin inhibitors }\end{array}$ & 8.2 & 7.8 & 9.8 & 8.9 & 0.24 & 0.032 & \\
\hline $\mathrm{TIU} / \mathrm{mg}$ & 1.8 & 1.8 & 1.6 & 1.6 & 0.40 & & \\
\hline
\end{tabular}

the presence of tannins in a diet may decrease the apparent protein digestibility in pigs (Jansman et al., 1992). However, the tannin/protein interactions may be specific for different tannins as well as for different proteins (Asquith and Butler, 1986). One of the main antinutritive effects of trypsin inhibitors in a diet is overstimulation of the exocrine activity of the pancreas (Savelkoul et al., 1992). Trypsin inhibiting activity did not vary considerably (1.6-1.8 TUI/mg DM) among the tested cultivars. Valdebouze et al. (1980), also using the Kakade (1974) method, but with different modifications, reported higher trypsin inhibitor levels ( 3.3 to $6.2 \mathrm{TUI} / \mathrm{mg} \mathrm{DM}$ ) and their greater variability among cultivars of faba beans.

The content and chemical composition of oligosaccharides and non-starch polysaccharides is given in Table 2 . The mean sucrose values for cultivars ranged from 14.1 to $16.7 \mathrm{~g} / \mathrm{kg} \mathrm{DM}$, which on average constituted $36 \%$ of the determined oligosaccharides. It was shown that cultivar and year of harvest highly influenced the sucrose content. A similar content of sucrose $(16.7 \mathrm{~g} / \mathrm{kg} \mathrm{DM})$ was found in dehulled beans (Dandanell Daveby and Åman, 1993). In the present study 
TABLE 2

The content and chemical composition of oligosaccharides and non-starch polysaccharides (NSP) in faba beans, $\mathrm{g} / \mathrm{kg} \mathrm{DM}$

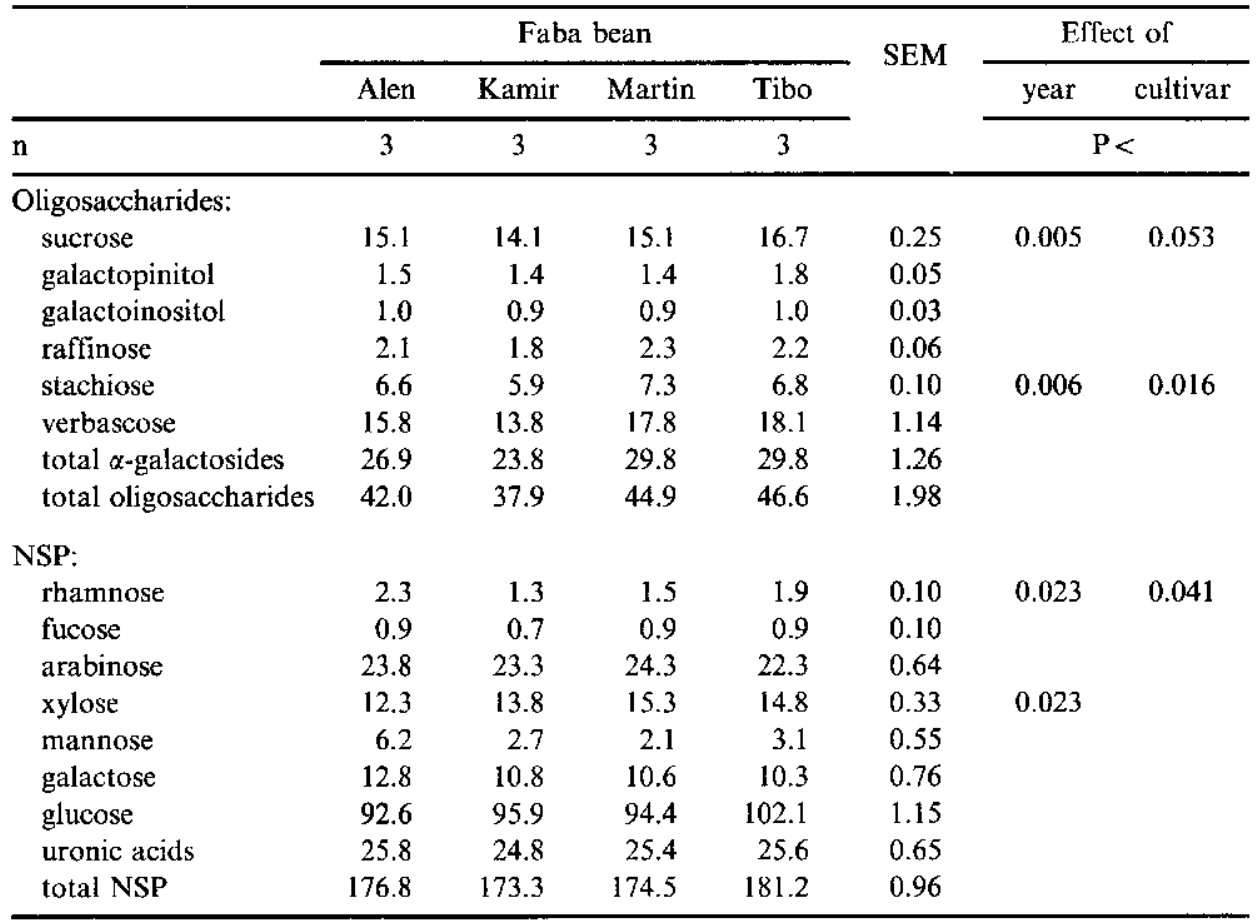

verbascose accounted for $59 \%$ and stachyose for $24 \%$ of total $\alpha$-galactosides in faba beans. The level of stachyose in beans depended on both the cultivar and the year of harvest. The raffinose content was low (about $8 \%$ of $\alpha$-galactosides) and similar in all cultivars. The results of a study by Dandanell Daveby and Åman (1993) indicated that verbascose and raffinose were the dominating $\alpha$-galactosides in dehulled faba beans. The tested beans also contained small quantities of galactopinitol and galactoinositol, which is in agreement with the results of Sosulski et al. (1982). Fifty-five percent of whole faba bean NSP was glucose. The average proportions of other NSP constituents, uronic acids (14\%), arabinose $(13 \%)$, xylose $(8 \%)$ and galactose $(6 \%)$ were in the intermediate range, while mannose $(2 \%)$, rhamnose $(1 \%)$ and fucose $(0.5 \%)$ were minor sugar residues. In dehulled faba beans, arabinose, glucose and uronic acids were the main NSP residues, while hull fibres were chiefly composed of glucose and, to a lesser extent, of uronic acids, xylose and Klason lignin (Dandanell Daveby and Åman, 1993). 


\section{Pisum sativum}

Pisum sativum hortense. The chemical composition of smooth seeds of whiteflowered peas is presented in Table 3 . The weight of 1000 seeds ranged from 146 to $272 \mathrm{~g}$ and significantly differed among cultivars. The seeds contained from 220 to $273 \mathrm{~g} / \mathrm{kg}$ DM of crude protein, and the difference among cultivars was significant. The crude protein content reported by Hove et al. (1978) ranged from 205 to $226 \mathrm{~g} / \mathrm{kg}$ DM. There are numerous causes of variability in the content of crude protein, including genetic (variety), cultural and environmental (soil, climate) origins (UNIP-ITCF, 1995). Starch is the most abundant component of peas. The content of total (444-520 $\mathrm{g} / \mathrm{kg} \mathrm{DM}$ ) and enzyme susceptible (391-447 $\mathrm{g} / \mathrm{kg} \mathrm{DM}$ ) starch in pea seeds significantly differed among cultivars. Despite this, the average total starch level was similar to that $(480 \mathrm{~g} / \mathrm{kg})$ determined by Cerning-Bernard and Filiatre (1976). According to Colonna et al. (1992) pea starch contained $33.2 \%$ amylose and $64.7 \%$ amylopectin.

Significant differences in the content of ether extract were observed among harvest years of peas. Pea seeds contained from 160 to $201 \mathrm{~g}$ of NSP and from 106 to $132 \mathrm{~g}$ of NDF per $\mathrm{kg}$ of dry matter, but the differences in the content of the fibre fractions either among cultivars or years were not significant. Statistically significant differences among cultivars were observed in the content of ADF and CF. Similarly, the level of cellulose $(55-80 \mathrm{~g} / \mathrm{kg} \mathrm{DM})$ in seeds was influenced by both cultivar and year of growth. Peas had from 24 to $49 \mathrm{~g} / \mathrm{kg} \mathrm{DM}$ hemicelluloses. Cerning-Bernard and Filiatre (1976) determined somewhat more $(50.6 \mathrm{~g} / \mathrm{kg} \mathrm{DM})$ hemicelluloses in pea seeds.

Seeds of white-flowered pea cultivars contained rather low levels of condensed tannins (about $0.4 \mathrm{mg} / \mathrm{g}$ DM). This confirms an earlier observation of Griffiths (1981), who reported $0.6 \mathrm{mg} / \mathrm{kg} \mathrm{DM}$ of these compounds in seeds of whiteflowered peas. Trypsin inhibitor activity was below $4 \mathrm{TUI} / \mathrm{mg}$ DM in the tested peas. Similar values (mostly below $3 \mathrm{TU} / \mathrm{mg}$ DM) were determined in spring varieties of pea by Leterme et al. (1990).

Pea contains considerable amounts of oligosaccharides, ranging from 77.0 to $92.4 \mathrm{~g} / \mathrm{kg} \mathrm{DM}$ (Table 4). The major ones are sucrose, representing on average $32 \%$ of total oligosaccharides, and the $\alpha$-galactosides. The latter, of which the principal ones are stachyose (18.1-33.1 g), verbascose (15.9-34.5 g) and raffinose (4.9-9.5 $\mathrm{g} / \mathrm{kg} \mathrm{DM})$, were found in the range from $53.4-62.6 \mathrm{~g} / \mathrm{kg} \mathrm{DM}$. This is in accordance with results of Cerning-Bernard and Filiatre (1976), who reported a similar proportion of $\alpha$-galactosides in smooth peas. These $\alpha$-galactosides of legume seeds are responsible for flatulence, particularly in pigs. However, while this association has been made in the case of lupins and faba beans, it has not been proved in peas (UNIP-ITCF, 1995). 


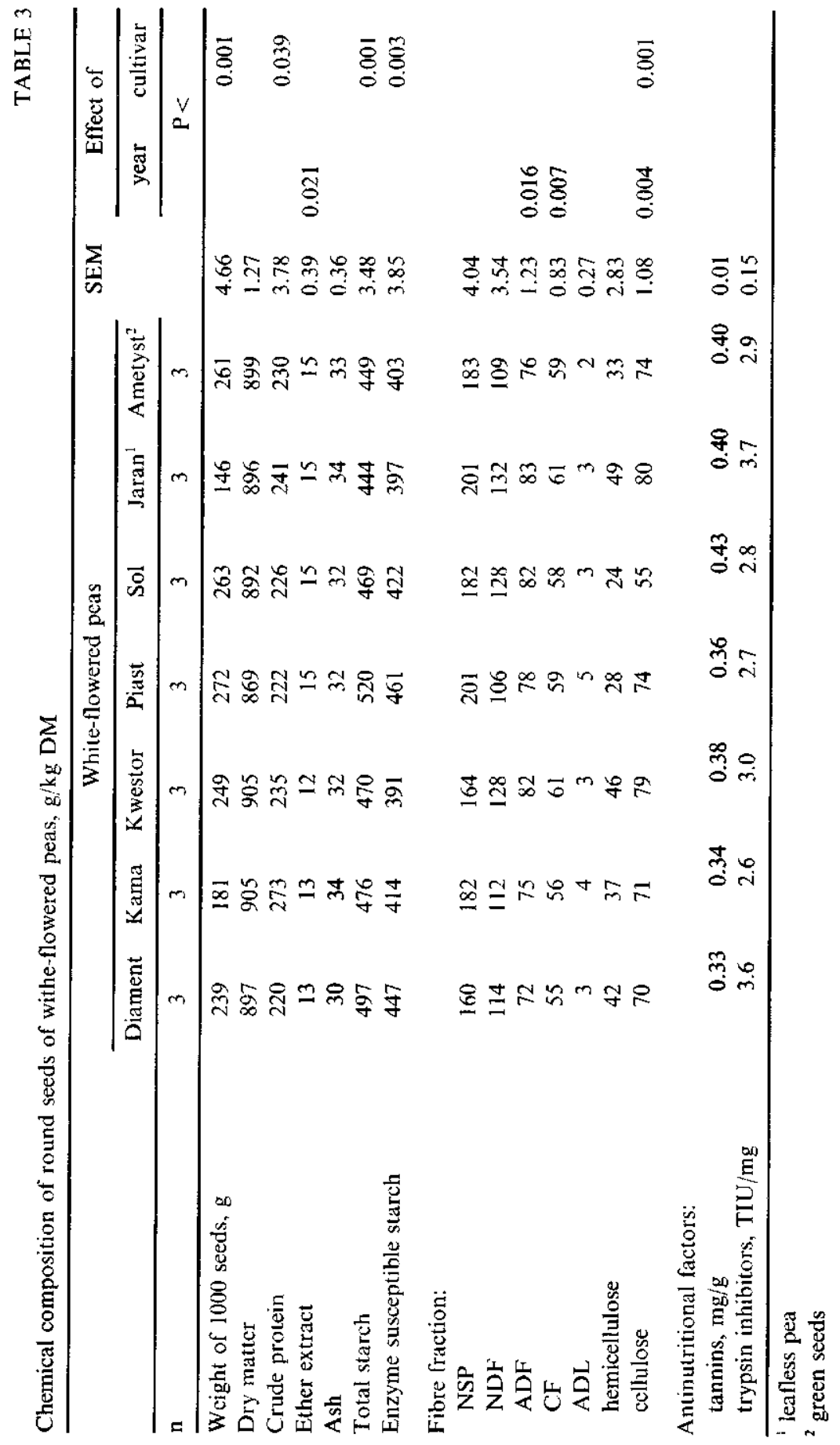




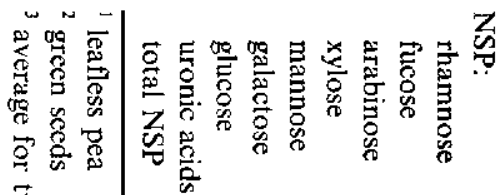

छั

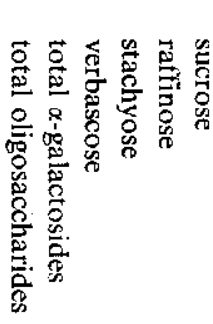

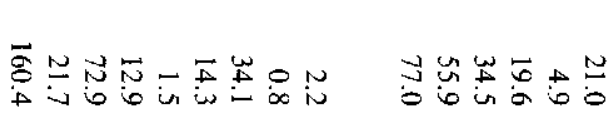

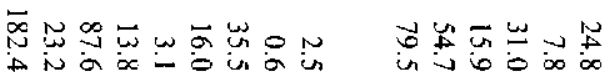

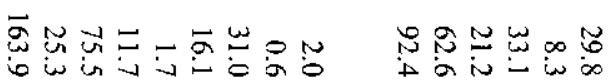

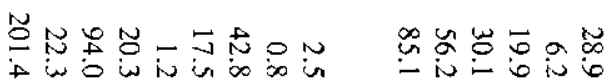

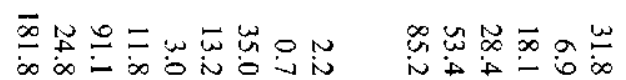

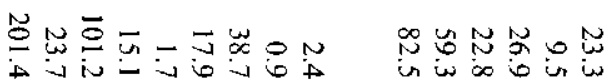

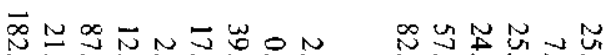

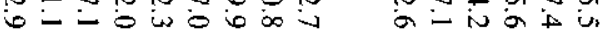

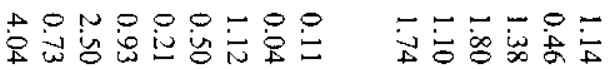

怘㤩

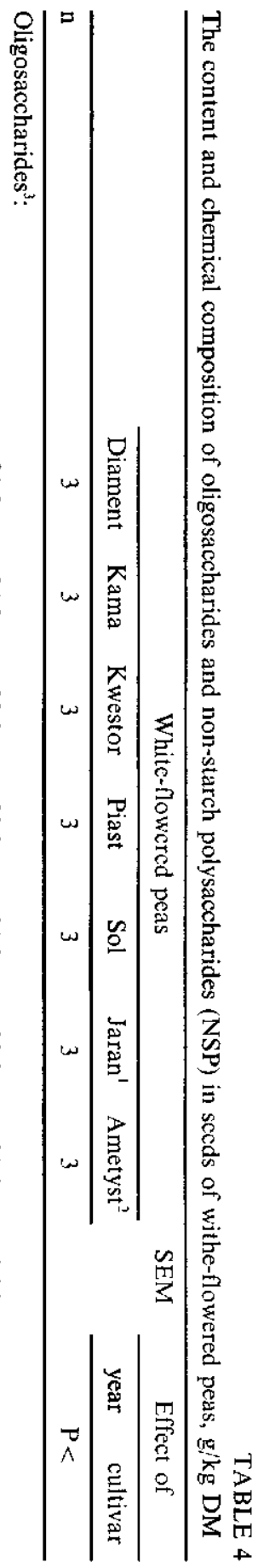


No notable differences in the composition of non-starch polysaccharides were found in the different peas. They were mainly composed of glucose and arabinose, which accounted on average for 48 and $20 \%$ of total NSP monosaccharide residues, respectively. The respective proportions for uronic acids $(13 \%)$, xylose $(9 \%)$ and galactose $(8 \%)$ were much lower. Rhamnose, mannose and fucose were minor components of pea seed NSP. Studies of Ralet and Thibault (1992) showed that dietary fibre of pea hulls $(91.5 \%)$ was composed mainly of glucose $(45.1 \%)$, xylose $(14.6 \%)$ and galacturonic acid $(12.7 \%)$. Such a chemical composition points to high contents of cellulose, xylans and pectic substances. Arabinose, uronic acids and glucose residues were the dominating dietary fibre components in dehulled peas (Dandanell Daveby and Åman (1993).

Pisum sativum arvense. The weight of 1000 seeds of the two tested cultivars was 165 and $207 \mathrm{~g}$ (Table 5). The content of crude protein (222 and $241 \mathrm{~g} / \mathrm{kg} \mathrm{DM}$ ), ether extract, ash, total and enzyme susceptible starch was similar in seeds of both cultivars. The level of NSP (182 and $192 \mathrm{~g} / \mathrm{kg} \mathrm{DM}$ ) in seeds did not depend

TABLE 5

Chemical composition of seeds of coloured-flowered peas, $\mathrm{g} / \mathrm{kg}$ DM

\begin{tabular}{|c|c|c|c|c|c|}
\hline & \multicolumn{2}{|c|}{ Pea } & \multirow[t]{3}{*}{ SEM } & \multicolumn{2}{|c|}{ Effect of } \\
\hline & Grapis & Fidclia & & ycar & cultivar \\
\hline $\mathbf{n}$ & 3 & 3 & & \multicolumn{2}{|c|}{$\mathbf{P}<$} \\
\hline Weight of 1000 seeds, $g$ & 207 & 165 & 5.83 & & \\
\hline Dry matter & 900 & 904 & 0.76 & 0.013 & \\
\hline Crude protein & 222 & 241 & 3.00 & & \\
\hline Ether extract & 12 & 14 & 1.30 & & \\
\hline Ash & 30 & 34 & 0.78 & & \\
\hline Total starch & 472 & 445 & 10.05 & & \\
\hline Enzyme susceptible starch & 401 & 381 & 2.48 & & \\
\hline \multicolumn{6}{|l|}{ Fibre fraction: } \\
\hline NSP & 182 & 192 & 2.26 & 0.012 & \\
\hline NDF & 137 & 141 & 2.08 & & \\
\hline $\mathrm{ADF}$ & 92 & 97 & 0.94 & 0.015 & \\
\hline $\mathrm{CF}$ & 64 & 66 & 1.45 & & \\
\hline ADL & 5 & 4 & 0.55 & & \\
\hline hemicelluloses & 45 & 45 & 1.83 & & \\
\hline cellulose & 87 & 93 & 0.48 & 0.003 & 0.026 \\
\hline \multicolumn{6}{|l|}{ Antinutritional factors: } \\
\hline tannins, $\mathrm{mg} / \mathrm{g}$ & 6.0 & 8.0 & 0.36 & & \\
\hline trypsin inhibitors, TIU/mg & 3.3 & 2.7 & 0.33 & & \\
\hline$\alpha$-galactosides, $\mathrm{mg} / \mathrm{g}$ & 64 & 58 & 1.52 & & 0.017 \\
\hline
\end{tabular}


TABLE 6 The content and chemical composition of oligosaccharides and non-starch polysaccharides in seeds of coloured-flowered peas, $\mathrm{g} / \mathrm{kg} \mathrm{DM}$

\begin{tabular}{|c|c|c|c|c|c|}
\hline & \multicolumn{2}{|c|}{ Peat } & \multirow[t]{2}{*}{ SEM } & \multicolumn{2}{|c|}{ Effect of } \\
\hline & Grapis & Fidelia & & year & cultivar \\
\hline $\mathrm{n}$ & 3 & 3 & & & \\
\hline \multicolumn{6}{|l|}{ Oligosaccharides: } \\
\hline sucrose & 21.7 & 25.1 & 1.89 & & \\
\hline raffinose & 6.1 & 6.5 & 0.98 & & \\
\hline stachyose & 28.3 & 22.4 & 3.95 & & \\
\hline verbascose & 29.4 & 29.2 & 3.31 & & \\
\hline total $\alpha$-galactosides & 63.7 & 58.1 & 1.52 & & 0.017 \\
\hline total oligosaccharides & 85.4 & 83.2 & 0.73 & & \\
\hline \multicolumn{6}{|l|}{ NSP: } \\
\hline rhamnose & 2.2 & 2.1 & 0.25 & & \\
\hline fucose & 0.8 & 0.6 & 0.06 & & \\
\hline arabinose & 37.3 & 36.7 & 1.46 & & \\
\hline xylose & 15.9 & 12.7 & 0.99 & & \\
\hline mannose & 1.4 & 1.7 & 0.29 & & \\
\hline galactose & 13.6 & 15.2 & 0.99 & & \\
\hline glucose & 86.9 & 98.9 & 2.04 & 0.030 & \\
\hline uronic acids & 23.3 & 23.7 & 0.50 & & \\
\hline total NSP & 181.5 & 191.6 & 2.26 & 0.012 & \\
\hline
\end{tabular}

on the pea cultivar, but on the year of growth. The latter factor significantly influenced $\mathrm{ADF}$ and cellulose content. It was found that the seeds of coloured-flowered peas contained significantly more NDF (140 vs. $118 \mathrm{~g}$ ), ADF (94 vs. $78 \mathrm{~g}$ ), cellulose (90 vs. $75 \mathrm{~g}$ ) and condensed tannins ( $7.0 \mathrm{vs} .0 .4 \mathrm{mg}$ ) than seeds of white-flowered cultivars (Table 7).

The contents and chemical composition of oligosaccharides and NSP in seeds of coloured-flowered peas are presented in Table 6 . The sucrose content was 21.7 and $25.1 \mathrm{~g}$, that of $\alpha$-galactosides was 63.7 and $58.1 \mathrm{~g} / \mathrm{kg} \mathrm{DM}$ of seeds. Similarly to white-flowered peas, stachyose and verbascose were major components of ${ }^{*}$ $x$-galactosides. Raffinose was found at a level below $7 \mathrm{~g} / \mathrm{kg} \mathrm{DM}$. The same proportions of particular NSP residues were observed in coloured-flowered peas as in white-flowered ones (Table 8).

\section{CONCLUSIONS}

Although faba beans and pea seeds contain several antinutritional factors, they appear to be a potentially useful source of protein and energy for pigs. The 
TABLE 7

Comparison of seed chemical composition between whitc- and coloured-flowered peas, $\mathrm{g} / \mathrm{kg}$ DM

\begin{tabular}{lccc}
\hline & \multicolumn{2}{c}{ Pea } & SEM \\
\cline { 2 - 3 } & white-flowered & coloured-flowered & \\
\hline Weight of 1000 seeds, g & 7 & 2 & 8.75 \\
Dry matter & 230 & 185 & 2.03 \\
Crude protein & 898 & 902 & 4.24 \\
Ether extract & 235 & 231 & 0.49 \\
Ash & 14 & 13 & 0.43 \\
Total starch & 32 & 32 & 8.24 \\
Enzyme susccptiblc starch & 461 & 459 & 5.19 \\
Fibre fraction: & 419 & 390 & \\
$\quad$ NSP & & & 4.79 \\
NDF & 182 & 186 & 2.89 \\
ADF & $118^{\mathrm{b}}$ & $140^{\mathrm{a}}$ & 1.65 \\
CF & $78^{\mathrm{b}}$ & $94^{\mathrm{a}}$ & 1.02 \\
ADL & 58 & 65 & 0.30 \\
hemicclluloses & 3 & 4 & 2.67 \\
cellulose & 37 & 45 & 2.11 \\
Antinutritional factors: & $75^{\mathrm{b}}$ & $90^{\mathrm{a}}$ & \\
tannins, mg/g & & & 0.36 \\
trypsin inhibitors, TIU/mg & $0.4^{\mathrm{b}}$ & $7.0^{\mathrm{a}}$ & 0.17 \\
\hline
\end{tabular}

$a, b-P \leqslant 0.05$

TABLE 8

Comparison of content and composition of oligosaccharides and non-starch polysaccharides between white- and coloured-flowered peas, $\mathrm{g} / \mathrm{kg} \mathrm{DM}$

\begin{tabular}{lccc}
\hline & \multicolumn{2}{c}{ Pea } & SEM \\
\cline { 2 - 3 } & \multicolumn{2}{c}{ white-flowered } & coloured-flowered \\
\cline { 2 - 3 } $\mathrm{n}$ & 7 & 2 & \\
\hline Oligosaccharides: & & & \\
$\quad$ sucrosc & 26.4 & 23.4 & 1.07 \\
raffinose & 7.3 & 6.3 & 0.44 \\
stachyose & 24.9 & 25.3 & 1.54 \\
verbascose & 24.9 & 29.9 & 1.62 \\
total $\alpha$-galactosides & 57.1 & 61.5 & 0.97 \\
total oligosaccharides & 83.5 & 84.9 & 1.42 \\
NSP: & & & \\
$\quad$ rhamnose & 2.4 & 2.2 & 0.10 \\
fucose & 0.7 & 0.7 & 0.04 \\
arabinose & 36.7 & 37.0 & 1.38 \\
xylose & 16.0 & 14.3 & 0.69 \\
mannose & 2.1 & 1.5 & 0.21 \\
galactose & 14.7 & 14.4 & 0.93 \\
glucose & 86.3 & 92.9 & 2.80 \\
uronic acids & 23.1 & 23.5 & 0.53 \\
total NSP & 182.0 & 186.4 & 4.79 \\
\hline
\end{tabular}


crude protein content both in faba bean and pea seeds is intermediate between that in soyabean and grains. The level of starch is high and, in some pea cultivars, it accounts for even $50 \%$ dry matter. Enzyme resistant starch is found in somewhat higher amounts in faba beans and coloured-flowered peas (13-16\% of total starch) than in white-flowered pea cultivars. Peas, particularly white-flowered cultivars, contain a low level of tannins. $\alpha$-Galactosides, present at higher levels in pea seeds than in faba beans, can be a cause of flatulence after feeding.

\section{REFERENCES}

AOAC., 1990. Official Methods of Analysis of the Association of Official Analytical Chemist. 15th Edition, Chapter 32, Washington, DC

Asquith T., Butler L., 1986. Interactions of condensed tannins with selected proteins. Phytochemistry $25,1591-1593$

Cerning-Bernard J., Filiatre A., 1976. A comparison of the carbohydrate composition of legume seeds: horse beans, peas and lupines. Cereal Chem. 53, 968-978

Colonna P., Bulcon A., Doublier J.L., 1992. Structural features of smooth and wrinkled peas starches. Proceedings of 1st European Conference on Legume Grains, Angers, pp. 401-402

Dandanell Daveby Y., Aman P., 1993. Chemical composition of certain dehulled legume seeds and their hulls with special reference to carbohydrates. Swedish J. Agric. Res. 23, 133-139

Gdala J., Buraczewska L., 1996. Chemical composition and carbohydrate content of seeds from several lupin species. J. Anim. Feed Sci. 5, 403-416

Griffiths D.W., 1981. The polyphenolic content and enzyme inhibitory activity of faba bean (Vicia faba) and pea (Pisum spp.) varietics. J. Sci. Food Agric. 32, 797-804

Griffiths D.W., 1983. Some anti-nutritive factors in Vicia faba. Newsletter, Faba bean Information Service $6,1-3$

Hove E.L., King S., Hill G.D., 1978. Composition, protein quality, and toxins of seeds of the grain legumes Glycine max, Lupinus spp., Phaseolus spp., Pisum sativum, and Vicia faba. N.Z.J. Agric. Res. 21, 457-462

Jansman A.J.M., Huisman J., Verstegen M.W.A., 1992. The effects of condensed tannins in faba bean hulls (Vicia faba $\mathrm{L}$.) on the ileal digestibility in piglets of diets containing different protein sources. Proceedings of 1st European Conference on Legume Grains, Angers, pp. 523-524

Kakade M.L., Rackis J.J., McGhec J.E., Puski G., 1974. Determination of trypsin inhibitor activity of soy products: a collaborative analysis of an improved procedure. Cereal Chem. 51, 276-282

Kuhla S., Ebmeier C., 1981. Unterschungen zum Tanningehalt in Ackerbohnen. Arch. Tierenähr. 31, 573-588

Leterme P., Beckers Y., Thewis A., 1990. Trypsin inhibitors in peas: varietal effect and influence on digestibility of crude protein by growing pigs. Anim. Feed Sci. Technol. 29, 45-55

Longstaff M., McNab J.M., 1987. Digestion of starcb and fibre carbohydrates in peas by adult cockerels. Brit. Poultry Sci. 28, 261-283

Marquardt R.R., McKirdy J.A., Ward T., Campbell L.D., 1975. Amino acids, hemagglutinin and trypsin inhibitor levels, and proximate analyses of faba beans (Vicia faba) and faba bean fractions. Can. J. Anim. Sci. 55, 421-429 
Megazyme, 1992. Enzyme susccptible starch assay procedure, TSA/92. Australia

Ralet M.C., Thibault J.F., 1992. Composition, structure, and physico-chemical properties of commercial pea hull fibers. Proceedings of 1st European Conference on Legume Grains, Angers, pp. 407-408

Saini H.S., 1993. Distribution of tannins, vicine and convicine in legume seeds. In: Recent $\Lambda$ dvances of Research in Antinutritional Factors in Legume Seeds. EAAP Publication no 70, pp. 95-100

Savage G.P., 1989. Antinutritional factors in peas. In: J. Huisman, A.F.B. van der Poel, I. E. Liencr (Editors). Recent Advances of Research in Antinutritive Factors in Legume Seeds. PUDOC, Wageningen, pp. 342-350

Savelkoul F.H.M.G., van der Pocl A.F.B., Tamminga S., 1992. The presence and inactivation of trypsin inhibitors, tannins, lectins and amylase inhibitors in legume seeds during germination. A review. Plant Foods Human Nutr. 42, 71-82

Sosulski F., Elkowicz L., Reichert R.D., 1982. Oligosaccharides in eleven legumes and their air-classified protein and starch fractions. J. Food Sci. 47, 498-502

Statgraphics Plus vr 7.0, 1993. Statistical Graphics System by Graphics Corporation

Telek L., Miklas P., 1993. Estimation of condensed tannins in faba beans (Vicia faba L.). In: Recent Advances of Research in Antinutritional Factors in Legume Seeds. EAAP Publication no 70 , pp. $117-120$

Thacker P.A., Bowland J.P., 1985. Faba beans: an aiternative protcin supplement for use in pig diets. Pig News Infor. 6, 25-30

UNIP-ITCF, 1995. Peas - utilization in animal feeding. 2nd Edition. UNIP, France, Chapter 1.1 Valdebouze P., Bergeron E., Gaborit T., Delort-Laval J., 1980. Content and distribution of trypsin inhibitors and hemagglutinins in some legume seeds. Can. J. Plant Sci. 60, 695-701

Van Oort M.G., Hamer R.J., Slager A.E., 1989. The trypsin inhibitor assay: improvement of existing method. In: J. Huisman, A.F.B. van der Poel, I.E. Liener: (Editors). Recent Advances of Rescarch in Antinutritional Factors in Legume Seeds. PUDOC, Wageningen, pp. 10-113

\section{STRESZCZENIE}

Sklad chemiczny i zawartość węglowodanów w nasionach różnych odmian bobiku i grochu

Oznaczono sklad chemiczny nasion czterech odmian bobiku (Vicia faba L.), sicdmiu odmian grochu (Pisum sativum hortense L.) oraz dwóch odmian pcluszki (Pisum sativum arvense I.). Nasiona bobiku zawicrały średnio $430 \mathrm{~g} / \mathrm{kg} \mathrm{s.m.} \mathrm{skrobi} \mathrm{ogólnej} \mathrm{i} 367 \mathrm{~g} / \mathrm{kg}$ s.m. skrobi podatnej na działanie cnzymów ( $\alpha$-amylazy i amyloglukozydazy). W suchej masie nasion grochu i peluszki oznaczono, odpowiednio, 461 i 459 g skrobi ogólnej oraz 419 i 390 g skrobi podatncj na dzialanic cnzymów. Nasiona bobików zawieraly mniej $\alpha$-galaktozydów ( 28 vs $58 \mathrm{~g}$ ) niż nasiona badanych grochów. Werbaskoza byla głównym składnikiem $\alpha$-galaktozydów nasion bobiku, natomiast werbaskoza i stachioza dominowały wśród $\alpha$-galaktozydów nasion grochu. Nasiona bobiku zawieraly $177 \mathrm{~g} / \mathrm{kg}$ s.m. polisacharydów nieskrobiowych (NSP), a grochów - $183 \mathrm{~g}$. Głównym składnikiem NSP nasion bobiku i grochu była glukoza, arabinoza i kwasy uronowe. 